\title{
VIRULOTYPING OF SHIGELLA SPP. ISOLATED FROM PEDIATRIC PATIENTS IN TEHRAN, IRAN
}

\author{
REZA RANJBAR $^{1 *}$, MASOMEH BOLANDIAN ${ }^{1}$ and PAYAM BEHZADI ${ }^{2}$ \\ ${ }^{1}$ Molecular Biology Research Center, Baqiyatallah University of Medical Sciences, \\ Tehran, Iran \\ ${ }^{2}$ Department of Microbiology, College of Basic Sciences, Shahr-e-Qods Branch, Islamic \\ Azad University, Tehran, Iran
}

(Received: 18 May 2016; accepted: 27 October 2016)

\begin{abstract}
Shigellosis is a considerable infectious disease with high morbidity and mortality among children worldwide. In this survey the prevalence of four important virulence genes including ial, ipaH, set $1 A$, and set $1 B$ were investigated among Shigella strains and the related gene profiles identified in the present investigation, stool specimens were collected from children who were referred to two hospitals in Tehran, Iran. The samples were collected during 3 years (2008-2010) from children who were suspected to shigellosis. Shigella spp. were identified throughout microbiological and serological tests and then subjected to PCR for virulotyping. Shigella sonnei was ranking first $(65.5 \%)$ followed by Shigella flexneri $(25.9 \%)$, Shigella boydii (6.9\%), and Shigella dysenteriae (1.7\%). The ial gene was the most frequent virulence gene among isolated bacterial strains and was followed by $i p a H, \operatorname{set} 1 \mathrm{~B}$, and set $1 A$. S. flexneri possessed all of the studied virulence genes (ial $65.51 \%$, ipaH $58.62 \%$, set $1 A 12.07 \%$, and set1B $22.41 \%$ ). Moreover, the pattern of virulence gene profiles including ial, ial-ipaH, ial-ipaH-set1B, and ial-ipaH-set1B-set1A was identified for isolated Shigella spp. strains. The pattern of virulence genes is changed in isolated strains of Shigella in this study. So, the ial gene is placed first and the ipaH in second.
\end{abstract}

Keywords: Shigella, shigellosis, virulence gene, gene profile, PCR

\section{Introduction}

Bacterial dysentery, red diarrhea, or shigellosis is a well-known infectious disease that spreads via contaminated foods and water. Shigellosis threats children's health care via high rates of morbidity and mortality among pediatric populations worldwide and in particular developing countries. The infection of

\footnotetext{
*Corresponding author; E-mail: ranjbarre@gmail.com
} 
shigellosis is caused by non-motile, facultative anaerobic Gram-negative coccobacilli of Shigella spp. Shigella spp. are categorized into four species of Shigella dysenteriae (A serogroup), Shigella flexneri (B serogroup), Shigella boydii (C serogroup), and Shigella sonnei (D serogroup). The shigellosis is identified throughout its clinical symptoms including enteric cramps, nausea, diarrhea, vomiting, blood, and mucus in stool, dehydration, and fever. The spectrum of red diarrhea varies from mild to severe [1-10].

Shigella, as an important pathogenic member of Enterobacteriaceae family is able to suppress the host's immune system to have successful adhesion and colonization within the intestine milieu. The epidemiological studies reveal that shigellosis is very common among young children within the age range of up to 5 years old. Thus, the annual mortality rate in association with shigellosis is estimated as $1.1 \times 10^{6}$ patients in which only one-third of them are above 5 years old. Climate, improper medical health care system, inappropriate individual hygiene, contaminated food, incorrect sanitation, and the virulence potential of Shigella species are the considerable risk factors that predispose the infection of shigellosis among different geographic populations. [1-3, 5, 11-14].

The invasive infection of shigellosis is demonstrated through 1-2 days after the entrance of 10-100 bacterial cells of Shigella within human digestive tract. There are different bacterial virulence factors which may lead to clinical manifestations, such as intestinal inflammatory responses and watery diarrhea. The plasmid encoded gene of ial (invasion associated locus) enables Shigella bacteria to penetrate into the intestinal epithelial tissues while plasmid encoded ipaH gene (invasion plasmid antigen $\mathrm{H}$ ) provides the capability of bacterial cell-to-cell movement and dissemination within epithelial cells of intestine. On the other hand, the chromosomal genes of set $1 A$ and set $1 B$ encode the iron-dependent protein of enterotoxin 1, which is known as a hexamerShET-1 protein. The ShET-1 protein, which is constituted of a subunit of A and five subunits of $\mathrm{B}$, is responsible for clinical manifestation of watery diarrhea. The A subunit is secreted by $\operatorname{set} 1 A$ and the $\mathrm{B}$ subunits are produced by $\operatorname{set} 1 B[15-17]$.

The infectious disease of shigellosis is an important bacterial pathogenic infection with high rate morbidity among Iranian pediatric populations too. Detection and identification of pathogenic strains support us to control and reduce the rate of shigellosis outbreaks among children. Therefore, the application of an accurate and reliable diagnostic technique like polymerase chain reaction (PCR) is necessary $[1,3,11,18,19]$.

Hence, in this study the authors tried to detect and identify the distribution of four important virulence genes of $i a l$, ipa $H$, set1 $A$, and setlB among clinical samples. 


\section{Materials and Methods}

\section{Isolated bacterial strains}

Diarrheal stool samples were taken from pediatric patients who were suspected to have shigellosis and referred to two pediatric hospitals in Tehran, Iran during 3 years (from 2008 to 2010).

The collected diarrheal stool samples were transferred from hospitals to laboratory in transport medium of Cary Blair for microbiological assays. Less than $5 \mathrm{~h}$, the fecal specimens were inoculated into different culture media including Hektoen enteric agar, MacConkey agar, Salmonella-Shigella agar, and xylose lysine deoxycholate agar (Difco, Detroit, MI, USA) and then were incubated for $24 \mathrm{~h}$ at $37^{\circ} \mathrm{C}$. The positive colonies were checked for further microbiological tests like Gram staining, microscopic observations, morphological macroscopic characteristics of the colonies, and API20E test kit. The positive samples were processed for biochemical properties including lactose fermentation and motility [3].

\section{Serotyping procedures}

In parallel with microbiological and biochemical analyses, the isolated Shigella strains were identified by serological procedures. The bacterial strains were inoculated into trypticase soy agar (Difco, Detroit, MI, USA) and then were detected via commercial serological antisera. The bacterial serotyping was performed by slide agglutination with polyclonal antisera (Mast Group Ltd., Bootle, Merseyside) for observing the occurrence of agglutinations on the glass slides [3].

\section{Genotyping of the virulence genes}

The DNA molecules pertaining to isolated strains were extracted by boiling; a simple and easy method for DNA harvesting. In this study, four virulence related genes of ial, ipaH, set1A, and set1B in Shigella strains were selected for further investigations (Figures 1-4). The primers used in this study were previously designed (Table I) [17, 20-22].

Each individual pair of aforementioned primers was optimized distinctly. A single $20 \mu \mathrm{l}$-PCR reaction mixture was consisted of $9 \mu \mathrm{l}(2 \times)$ master mix, $1 \mu 1$ $(50 \mathrm{pmol})$ related forward primer, $1 \mu \mathrm{l}(50 \mathrm{pmol})$ related reverse primer, $1 \mu \mathrm{l}$ $(2 \mu \mathrm{g} / \mu \mathrm{l})$ DNA template, and $8 \mu \mathrm{l}$ sterile double distilled water. The amplification process was achieved by Eppendorf thermal cycler. The cycling program was 


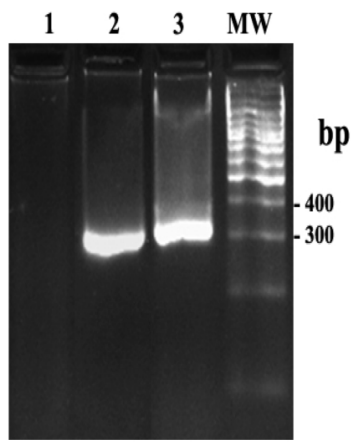

Figure 1. Detection of ial gene ( $320 \mathrm{bp})$ by PCR in Shigella strains. Lanes 2 and 3: positive representative strains; lane 1: negative representative strain. MW is molecular ladder (100 bp)

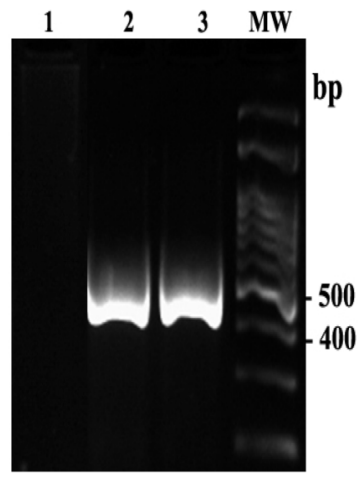

Figure 2. Detection of ipaH gene (430 bp) by PCR in Shigella strains. Lanes 2 and 3: positive representative strains; lane 1 : negative representative strain. MW is molecular ladder (100 bp)

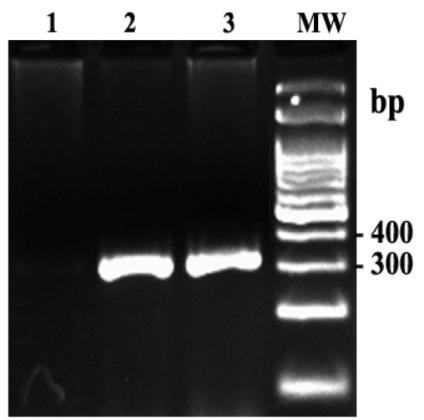

Figure 3. Detection of set $1 A$ gene (309 bp) by PCR in Shigella strains. Lanes 2 and 3: positive representative strains; lane 1: negative representative strain. MW is molecular ladder (100 bp) 


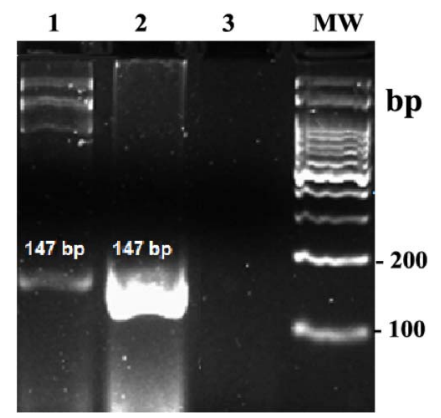

Figure 4. Detection of $\operatorname{set} 1 B$ gene $(147 \mathrm{bp})$ by PCR in Shigella strains. Lanes 1 and 2: positive representative strains; lane 3: negative representative strain. MW is molecular ladder (100 bp)

Table I. Virulence-related genes and their primers [17, 20-22]

\begin{tabular}{lll}
\hline Virulence gene & Primer & $5^{\prime} \rightarrow 3^{\prime}$ nucleotide sequences \\
\hline ial & ial & CTG GAT GGT ATG GTG AGG \\
& & GGA GGC CAA CAA TTA TTT CC \\
ipaH & Shig1 & TGG AAA AAC TCA GTG CCT CT \\
\multirow{2}{*}{ set1A } & Shig2 & CCA GTC CGT AAA TTC ATT CT \\
\multirow{2}{*}{ set $1 B$} & ShET1A & TCA CGC TAC CAT CAA AGA \\
& ShET1B & TAT CCC CCT TTG GTG GTA \\
& & GTG AAC CTG CTG CCG ATA TC \\
& & ATT TGT GGA TAA AAA TGA CG \\
\hline
\end{tabular}

constructed of a single 7 -min cycle of initial denaturation at $95{ }^{\circ} \mathrm{C}$, a 1 -min template denaturation at $94{ }^{\circ} \mathrm{C}(30$ cycles $)$, a 1 -min annealing at $52^{\circ} \mathrm{C}(30$ cycles $)$, a 1 -min extension at $72{ }^{\circ} \mathrm{C}$ ( 30 cycles), and a single 7 -min cycle of final extension at $72{ }^{\circ} \mathrm{C}$. Finally, the PCR productions were run on $2 \%$ gel electrophoresis. The fluorochrome of SYBR GREEN was used in gel electrophoresis (Figures 1-4).

Moreover, the amplified DNA nucleotide sequences were compared with gene sequences registered at gene database, National Center for Biotechnology Information (NCBI).

\section{Results}

According to the performed microbiological, biochemical, and serological tests in this study, all the subgroups involving $S$. sonnei, S. flexneri, S. boydii, and $S$. dysenteriae were detected within collected clinical samples of diarrheal stool. So, the most isolated subgroup was pertaining to $S$. sonnei $(65.51 \%)$ and the least one was related to $S$. dysenteriae $(1.7 \%)$. 
Table II. Frequency of virulence genes in Shigella subgroups

\begin{tabular}{|c|c|c|c|c|c|c|}
\hline $\begin{array}{l}\text { Virulence } \\
\text { gene }\end{array}$ & Location & $\begin{array}{c}\text { Total } \\
(n=58), \\
n(\%)\end{array}$ & $\begin{array}{c}\text { S. sonnei } \\
(n=38), \\
n(\%)\end{array}$ & $\begin{array}{c}\text { S. flexneri } \\
(n=15), \\
n(\%)\end{array}$ & $\begin{array}{l}\text { S. boydii } \\
(n=4), \\
n(\%)\end{array}$ & $\begin{array}{c}\text { S. dysenteriae } \\
(n=1), \\
n(\%)\end{array}$ \\
\hline ial & Plasmid & $38(65.51)$ & $24(63.16)$ & $11(28.95)$ & $3(7.89)$ & $0(0.00)$ \\
\hline ipaH & $\begin{array}{l}\text { Plasmid-- } \\
\text { chromosome }\end{array}$ & $34(58.62)$ & $27(79.41)$ & $6(17.65)$ & $1(2.94)$ & $0(0.00)$ \\
\hline $\operatorname{set} 1 A$ & Chromosome & $7(12.07)$ & $0(0.00)$ & $6(85.71)$ & $1(14.29)$ & $0(0.00)$ \\
\hline $\operatorname{set} 1 B$ & Chromosome & $13(22.41)$ & $8(61.54)$ & $4(30.77)$ & $1(7.69)$ & $0(0.00)$ \\
\hline
\end{tabular}

Table III. Four different patterns for virulence gene profiles including ial gene in association with isolated Shigella serogroups from clinical specimens

\begin{tabular}{lccccc}
\hline & \multicolumn{5}{c}{ Diarrheal stool samples } \\
\cline { 2 - 6 } & $\begin{array}{c}\text { Total } \\
(n=58),\end{array}$ & $\begin{array}{c}\text { S. sonnei } \\
(n=38),\end{array}$ & $\begin{array}{c}\text { S. flexneri } \\
(n=15),\end{array}$ & $\begin{array}{c}\text { S. boydii } \\
(n=4),\end{array}$ & $\begin{array}{c}\text { S. dysenteriae } \\
(n=1),\end{array}$ \\
Virulence gene profile & $n(\%)$ & $n(\%)$ & $n(\%)$ & $n(\%)$ & $n(\%)$ \\
\hline ial [1] & $38(65.51)$ & $24(63.16)$ & $11(28.95)$ & $3(7.89)$ & $0(0.00)$ \\
ial-ipaH [2] & $23(39.66)$ & $18(47.37)$ & $4(26.67)$ & $1(25)$ & $0(0.00)$ \\
ial-ipaH-set1B [3] & $7(12.07)$ & $5(13.16)$ & $1(6.67)$ & $1(25)$ & $0(0.00)$ \\
ial-ipaH-set1B-set1A [4] & $2(3.45)$ & $0(0.00)$ & $1(6.67)$ & $1(25)$ & $0(0.00)$ \\
\hline
\end{tabular}

The frequencies of virulence genes involving $i a l$, ipaH, set $1 A$, and set $1 B$ were detected (Table II) and virulence gene profiles regarding Shigella subgroups were determined (Table III).

For detecting aforementioned virulence genes, the PCR assay was performed thrice and obtained the same results (Figures 1-4). No, amplification was done relating to genes of non-Shigella strains. This confirms $100 \%$ reproducibility for PCR.

The molecular weights of the genes including ial (320 bp), ipaH (430 bp), set1A (309 bp), and set1B (147 bp) were determined (Figures 1-4). The partial coding sequence (cds) genes belonging to set1A (accession numbers: KP116116.1, KP116115.1, KP116114.1, and KP116113.1) in S. flexneri, and ipaH (accession numbers: KP116110.1, KP116109.1, and KP116108.1) in S. sonnei were submitted to NCBI.

\section{Discussion}

Shigellosis as an important invasive enteric infectious disease may appear in different forms of sporadic, epidemic, and pandemic. According to geographical area, the rate of shigellosis and the causative subgroups are different; but the 
reported records show a considerable increase of the infection within developing countries [15, 23].

Sangeetha et al. have shown that $S$. flexneri was ranking first as the most important bacterial agent regarding to shigellosis among children. This situation has been reported from other countries like Brazil, China, and Egypt [2, 6, 15].

In our previous report, $S$. sonnei was the predominant bacterial agent of shigellosis in Iran which was similar to some countries such as Canada and the United States of America. However, in some recent reports S. flexneri was identified as first [6, 24-27].

As mentioned before, the pathogenicity of Shigella spp. is in association with the presence of several virulence genes including ial, ipaH, $\operatorname{set} 1 \mathrm{~A}$, and $\operatorname{set} 1 \mathrm{~B}$. Therefore, in the present investigation the presence of the four aforementioned virulence genes were studied [2, 15, 17, 28, 29].

As the genetic diversity of Shigella subgroups varies in different countries and the knowledge about Shigella subgroups' virulence gene profiles is limited, we tried to represent a pattern in association with virulence gene profiles including ial, ipaH, $\operatorname{set} 1 A$, and $\operatorname{set} 1 B[2,30]$.

Farshad et al., Sousa et al., Thong et al., Bin Kingombe et al., Vargas et al., and Sangeetha et al. have indicated that ipaH was identified in all isolated Shigella spp. in their studies; while these results are not in accordance with our outcomes $[6,15,17,27,28,31]$.

In our study, the ial gene was the predominant gene among other studied bacterial strains. $63.16 \%$ of $S$. sonnei encompassed the ial gene. This result shows the high capacity of invasive property by ial gene among isolated strains which are charged by plasmids.

The ipaH gene was ranked in second place among isolated strains in this study. This outcome does not match the results showed by aforementioned authors. $S$. flexneri has the highest level (79.41\%) regarding to ipaH gene $[6,15,17,27,31]$.

As results show in our study, S. sonnei (47.37\%) ranked first for possessing $i p a H$ gene too; while no ipaH gene was recognized among $S$. dysenteriae.

The set 1 gene which regulates the secretion of enterotoxin was determined in isolated subgroups. $\operatorname{set} 1 B$ virulence gene was recognized in all isolated subgroups exclusive $S$. dysenteriae. The $\operatorname{set} 1 B$ is related to watery diarrhea and dehydration symptoms. set $1 A$ was identified neither in $S$. sonnei nor $S$. dysenteriae. The identified virulence gene profiles confirm the clinical conditions of the patients [2, 21, 32, 33].

da Cruz et al. have shown that the presence of $\operatorname{set} 1 A$ was more frequent than set $1 B$ in the isolated Shigella strains in their study, while Thong et al. have 
reported an equal percentage of the presence of $\operatorname{set} 1 A$ and $\operatorname{set} 1 B$ genes among the isolated bacteria in their survey $[2,17]$.

According to Noriega et al. and Vargas et al. surveys, our results show that $S$. flexneri possesses the most number of set $1 A$ and set $1 B$ genes as individuals. Furthermore in our research, the predominant Shigella subgroup isolated from 58 clinical specimens was $S$. sonnei. It was followed by $S$. flexneri, $S$. boydii, and $S$. dysenteriae. Several studies show that $S$. sonnei is the most important causative agent of shigellosis in modern and industrialized countries. This pattern confirms a clear improvement in public health and individual hygiene [11, 15, 24, 34].

In conclusion, our study represents a new pattern of frequencies in association with virulence genes of $i a l$, ipaH, set $1 A$, and set $1 B$. Our investigation shows the highest frequency of ial gene among Shigella strains and it is followed by $i p a H, \operatorname{set} 1 B$, and $\operatorname{set} 1 A$. Moreover, PCR typing is an appropriate method to find out virulence gene profiles regarding isolated bacteria. It helps scientist to put puzzle pieces to have a complete genetic data in association with different Shigella strains that cause shigellosis around the world. Finally, a clear virulence gene profile may lead to have an accurate diagnosis to have a definite treatment relating to different pathogenic strains.

\section{Conflict of Interest}

The authors declare no conflict of interest.

\section{References}

1. Farshad, S., Ranjbar, R., Hosseini, M.: Molecular genotyping of Shigella sonnei strains isolated from children with bloody diarrhea using pulsed field gel electrophoresis on the total genome and PCR-RFLP of IpaH and IpaBCD genes. Jundishapur J Microbiol 8, e14004 (2014).

2. da Cruz, C. B. N., de Souza, M. C. S., Serra, P. T., Santos, I., Balieiro, A., Pieri, F. A., Nogueira, P. A., Orlandi, P. P.: Virulence factors associated with pediatric shigellosis in Brazilian Amazon. BioMed Res Int 2014, 9 (2014).

3. Ranjbar, R., Mammina, C., Pourshafie, M. R., Soltan-Dallal, M. M.: Characterization of endemic Shigella boydii strains isolated in Iran by serotyping, antimicrobial resistance, plasmid profile, ribotyping and pulsed-field gel electrophoresis. BMC Res Notes 1, 74 (2008).

4. Behzadi, P., Behzadi, E.: Study of Microbial Biochemical Reactions in Bacteriology Laboratories, $1^{\text {st }}$ Edition. Persian Science \& Research Publisher, Tehran, Iran, 2012.

5. Baveja, U. K.: Shigellosis: An emerging water-related public health problem. In Singh P. P., Sharma V. (eds): Water and Health, $1^{\text {st }}$ Edition. Springer, India, 2014, pp. 107-117. 
6. Sangeetha, A., Parija, S. C., Mandal, J., Krishnamurthy, S.: Clinical and microbiological profiles of shigellosis in children. J Health Popul Nutr 32, 580-586 (2014).

7. Ranjbar, R., Soltan-Dallal, M. M., Pourshafie, M. R., Mammina, C.: Antibiotic resistance among Shigella serogroups isolated in Tehran, Iran. Infect Dis 11, 164-167 (2009).

8. Hosseini, M., Ranjbar, R., Ghasemi, H., Jalalian, H.: The prevalence and antibiotic resistance of Shigella sp. recovered from patients admitted to Bouali Hospital, Tehran, Iran during 1999-2001. Pak J Biol Sci 10, 2778-2780 (2007).

9. Hosseini, M. J., Kaffashian, A. R.: An outbreak of shigellosis due to Shigella flexneri serotype 3a in a prison in Iran. Arch Iran Med 13, 413 (2010).

10. Ranjbar, R., Ghazi, F. M.: Antibiotic sensitivity patterns and molecular typing of Shigella sonnei strains using ERIC-PCR. Iran J Public Health 42, 1151-1157 (2013).

11. Ranjbar, R., Aleo, A., Giammanco, G. M., Dionisi, A. M., Sadeghifard, N., Mammina, C.: Genetic relatedness among isolates of Shigella sonnei carrying class 2 integrons in Tehran, Iran, 2002-2003. BMC Infect Dis 7, 62 (2007).

12. Cash, B. A., Rodó, X., Emch, M., Yunus, M., Faruque, A. S., Pascual, M.: Cholera and shigellosis: Different epidemiology but similar responses to climate variability. PLoS One 9, e107223 (2014).

13. Ranjbar, R., Ghazi, F. M., Farshad, S., Giammanco, G. M., Aleo, A., Owlia, P., Jonaidi, N., Sadeghifard, N., Mammina, C.: The occurrence of extended-spectrum $\beta$-lactamase producing Shigella spp. in Tehran, Iran. Iran J Microbiol 5, 108 (2013).

14. Ranjbar, R., Dallal, M. S., Pourshafie, M., Aslani, M., Majdzadeh, R.: Serogroup distribution of Shigella in Tehran. Iran J Public Health 33, 32-35 (2004).

15. Sousa, M. Â. B., Mendes, E. N., Collares, G. B., Péret-Filho, L. A., Penna, F. J., Magalhães, P. P.: Shigella in Brazilian children with acute diarrhoea: Prevalence, antimicrobial resistance and virulence genes. Mem Inst Oswaldo Cruz 108, 30-35 (2013).

16. Frankel, G., Riley, L., Giron, J. A., Valmassoi, J., Friedmann, A., Strockbine, N., Falkow, S., Schoolnik, G. K.: Detection of Shigella in feces using DNA amplification. J Infect Dis 161, 1252-1256 (1990).

17. Thong, K. L., Hoe, S. L., Puthucheary, S., Yasin, R. M.: Detection of virulence genes in Malaysian Shigella species by multiplex PCR assay. BMC Infect Dis 5, 8 (2005).

18. Ranjbar, R., Afshar, D., Tavana, A. M., Najafi, A., Pourali, F., Safiri, Z., Zanjani, R. S., Jafari, N. J.: Development of multiplex PCR for simultaneous detection of three pathogenic Shigella species. Iran J Public Health 43, 1657-1663 (2014).

19. Ranjbar, R., Karami, A., Farshad, S., Giammanco, G. M., Mammina, C.: Typing methods used in the molecular epidemiology of microbial pathogens: A how-to guide. New Microbiol 37, 1-15 (2014).

20. Lüscher, D., Altwegg, M.: Detection of shigellae, enteroinvasive and enterotoxigenic Escherichia coli using the polymerase chain reaction (PCR) in patients returning from tropical countries. Mol Cell Probes 8, 285-290 (1994).

21. Fasano, A., Noriega, F., Maneval, D., Jr., Chanasongcram, S., Russell, R., Guandalini, S., Levine, M.: Shigella enterotoxin 1: An enterotoxin of Shigella flexneri 2 a active in rabbit small intestine in vivo and in vitro. J Clin Invest 95, 2853 (1995).

22. Frankel, G., Giron, J., Valmassoi, J., Schoolnik, G.: Multi-gene amplification: Simultaneous detection of three virulence genes in diarrhoeal stool. Mol Microbiol 3, 1729-1734 (1989). 
23. Bhattacharya, S. K., Sur, D., Mahalanabis, D.: Public health significance of shigellosis. Indian Pediatr 49, 269-270 (2012).

24. Ranjbar, R., Dallal, M. M. S., Talebi, M., Pourshafie, M. R.: Increased isolation and characterization of Shigella sonnei obtained from hospitalized children in Tehran, Iran. J Health Popul Nutr 26, 426 (2008).

25. MoezArdalan, K., Zali, M. R., Dallal, M. M. S., Hemami, M. R., Salmanzadeh-Ahrabi, S.: Prevalence and pattern of antimicrobial resistance of Shigella species among patients with acute diarrhoea in Karaj, Tehran, Iran. J Health Popul Nutr 21, 96-102 (2003).

26. Nikkah, J., Mehr-Movahead, A.: Antibiotic resistance among Shigella species isolated in Tehran, Iran. Ann Trop Med Parasitol 82, 481-483 (1988).

27. Farshad, S., Sheikhi, R., Japoni, A., Basiri, E., Alborzi, A.: Characterization of Shigella strains in Iran by plasmid profile analysis and PCR amplification of ipa genes. J Clin Microbiol 44, 2879-2883 (2006).

28. Vargas, M., Gascon, J., De Anta, M. T. J., Vila, J.: Prevalence of Shigella enterotoxins 1 and 2 among Shigella strains isolated from patients with traveler's diarrhea. J Clin Microbiol 37, 3608-3611 (1999).

29. Noriega, F. R., Liao, F. M., Formal, S. B., Fasano, A., Levine, M. M.: Prevalence of Shigella enterotoxin 1 among Shigella clinical isolates of diverse serotypes. J Infect Dis 172, 1408-1410 (1995).

30. Marteyn, B., Gazi, A., Sansonetti, P.: Shigella: A model of virulence regulation in vivo. Gut Microbes 3, 104-120 (2012).

31. Bin Kingombe, C. I., Cerqueira-Campos, M.-L., Farber, J. M.: Molecular strategies for the detection, identification, and differentiation between enteroinvasive Escherichia coli and Shigella spp. J Food Prot 68, 239-245 (2005).

32. Niyogi, S. K.: Shigellosis. J Microbiol 43, 133-143 (2005).

33. Fasano, A., Noriega, F., Liao, F., Wang, W., Levine, M.: Effect of Shigella enterotoxin 1 (ShET1) on rabbit intestine in vitro and in vivo. Gut 40, 505-511 (1997).

34. Filliol-Toutain, I., Chiou, C.-S., Mammina, C., Gerner-Smidt, P., Thong, K.-L., Phung, D. C., Pichel, M., Ranjbar, R., Sow, A. G., Cooper, K.: Global distribution of Shigella sonnei clones. Emerg Infect Dis 17, 1910 (2011). 